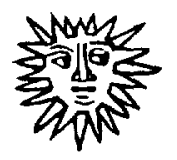

\title{
THE PERFORMING SPECTATOR IN ALEJO CARPENTIER'S FICTIONAL WORLD
}

\author{
VICKY UNRUH \\ University of Kansas
}

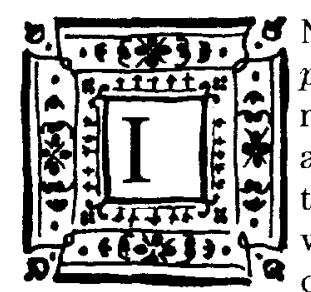

$\mathrm{N}$ the opening lines of Alejo Carpentier's Los pasos perdidos (1953), ${ }^{1}$ the nameless narrator-protagonist faces an antebellum, white-pillared house on a New Orleans-style street. A wrought-iron lantern, a rose trellis, dwarf magnolias, and a river walk embellish the scene, while a wine-colored curtain and wooden echoes underfoot hint at the scenario's deceit. When the protagonist steps offstage into a group of actors awaiting their cues, the reader discerns that this is a play set: "Al tiempo salí de la luz, pues sonó el disparo del cazador y un pájaro cayó en escena desde el segundo tercio de bambalinas. El miriñaque de mi esposa voló por sobre mi cabeza, pues me hallaba precisamente donde le tocara entrar, estrechándole el ya angosto paso" (68). This scene's most striking feature is the narrator's curious position. As the recalcitrant spectator of a dramatic scenario, he strolls through the fictitious space and pauses on the boundary between onstage and off, neither a participant in the drama nor a conventional audience member. This uncertain position anticipates the alienated protagonist's ontological dilemma throughout the novel, as he seeks the participatory immediacy of an earlier world as an anti-

\footnotetext{
${ }^{1}$ In multiple references, I use the following abbreviations for novel titles: $E Y O$ (Ecue-Yamba-O); ERM (El reino de este mundo); LPP (Los pasos perdidos); and ES (El siglo de las luces).
} 
dote to modern life. This scenario of liminality also highlights the cardinal role of performance in Carpentier's life-long inquiry into subjectivity and identity, his exploration of how individuals imagine themselves and their others within a culturally specific contingent world.

Performance in multiple guises constitutes an enduring motif in Carpentier's novelized universe, as narrators and characters witness and participate in a range of spectacles: circus side-shows, nánigo rituals, pastoral balls, staged plays, ballet, and opera. Critics have addressed the allegorical function of ritual and spectacle in El siglo de las luces and Los pasos perdidos, as well as the metaphor of the world's great stage weaving through Carpentier's entire novelistic production. ${ }^{2}$ But Aníbal González' lucid study of $E l$ arpa y la sombra is the most pertinent to my focus here because of its theoretical concerns. He argues that in this novel, theatre provides a metaphor for a self-referential textuality that is also the site of conflicting ethical positions. In examining Carpentier's obsession with performance, I, too, focus on shifting, sometimes conflictive positions, but of a more cultural and ontological kind. Much like the most innovative theatre practitioners of the twentieth century, Carpentier used the concept of performance as a point of departure for theoretical inquiry, specifically into changing notions of theatrical space and spectator-stage interaction. By performance I mean maneuvers before a real or imagined audience that encompass the body, the human voice or musical instruments, and space, as well as an actualizing of scripts, whether implicit or written, culturally acquired or improvised. Performance privileges that aspect of theatricality that is self-aware and unstable. Drawing on the ability of performance to "unmask the terms of representation," moreover, Herbert Blau spells out the kinship between theatre and theory as: "a model of inquiry with the idea of performance at the epistemological center" (Blooded Thought 30). Similarly, Barbara Freedman stresses the performative qualities of theatre that are ideally "suited to . . . subverting fields of representation," including "a refusal of the observer's stable position, a fascination

" On Carpentier's use of the gran teatro del mundo motif, see articles by Psiche Hughes, Arthur Natella, chapter 3 of Roberto González Echevarría's The Pilgrim at Home, and, for the most rigorous thematic analysis of Carpentier's use of this metaphor, Sally Harvey's chapter on "The Metaphor of the Theatre." Other recent studies of theatricality in Carpentier's narrative include articles by David Bost, Patrick Collard, and Aníbal González. 
with re-presenting presence, an ability to stage its own staging, to rethink, reframe, switch identifications, undo frames, see freshly" (73). Although it has been suggested that Carpentier used theatre metaphors to construct certain fixed images of the world, ${ }^{3}$ I would argue that his attention to performance was equally motivated by his interest in "switching identifications" in order to rethink and reframe the world.

In this light, Carpentier's own theatre activity of the 1920s and 1930s provides keys to his narrative universe. Through this body of work, including critical reviews of Parisian experiments and his own three dramatic compositions, Carpentier theorized about performance, in particular the spectator's shifting relationships to theatrical space. The concepts that emerge from this early work resonate in the theatricality of Carpentier's novels, not only in the performances that permeate them but also through the construction of narrator and character positions. As a result, in Carpentier's fiction, cultures are often characterized by the performances they create, identities are defined through shifting relationships between spectators and the events they witness, cross-cultural encounters are portrayed through competing enactments or divergently positioned audiences, and narrators and characters are often ambiguously situated on the mercurial boundary between the action and the audience of a performance. While this equivocal position can be the source of great anxiety (as it is for the angst-ridden protagonist of $L P P$ ), it also provides a productive way of thinking about culture and identity. In Carpentier's fiction, in fact, spectatorship becomes a dynamic activity that implies a concrete but alterable mode of perceiving and experiencing the world.

\section{Carpentier's Theatrical Inquiry}

Between 1928 and 1939 in Paris, Carpentier filed play reviews with the Cuban periodicals Social and Carteles. These texts reveal an early interest in deeper structures of theatre, particularly the complex relationship of spectator to performance site. During these years in-

\footnotetext{
:3n El siglo de las luces, for example, Hughes draws on González Echevarria's work to argue that representations, performances, and rituals "are elements of Carpentier's allegoric method of presenting history because their ceremonial nature invests the events with fixed meaning" (129).
} 
novators from Bertolt Brecht to Antonin Artaud were reconceptualizing theatrical space and radically challenging boundaries between actors and audience normalized by nineteenth-century drama. ${ }^{4} \mathrm{Car}$ pentier's articles on Brecht, Jean Cocteau, Luigi Pirandello, Max Reinhardt, Vsevolod Meyerhold, Kabuki theatre, and Italian puppetry testify to his meticulous observation of the changes they posed. The reviews reveal his fascination with the conceptual architectonics of theatrical space, his understanding of how a spectator's perspective is altered as that space is reconceived, and his captivation by the act and idea of watching. One is struck not only by the variety of theatrical events that Carpentier witnessed, but also by the fact that he became the spectators' audience and registered their reactions and watching styles. In an enthusiastic report on the Teatro di Piccoli marionettes, for example, he noted that ordinary spectators appeared impervious to the show's modernity and stylization (Crónicas 329), while the audience of a Reinhardt production appeared "conquered by the caricatures" (363). Even more striking is Carpentier's scrupulous attention to the impact that changes in spatial configuration or theatrical effects can have in manipulating spectator perceptions. A thoughtful review of the Brecht and Weill production of The Beggars' Opera emphasized these elements: "un sistema de tres barreras horizontales, que se cierran y abren a la vista del público . . . De este modo, la pieza se desarrolla con una rapidez cinematográfica, ante una variación continua de 'fondo' " (379; my emphasis). Carpentier found Meyerhold's work even more exciting in this regard, precisely because the Russian director's staging manipulated spectators to overcome the "eterna barrera" of the proscenium and focus on a specific point. Meyerhold, he explained, reduced the actors' field of action to a wooden parallelogram no larger than a boxing ring and substituted the curtain with a moveable partition. Under the "violent light" of four bulbs, the actors moved on a kind of inclined platform among small props that made them appear larger. The effect of these strategies, Carpentier observed, was a radical concentration of spectator attention: "se obtiene en el público una suerte de concentración de miradas sobre un punto único, equivalente al close-up cinematográfico. Los intérpretes parecen enormes. Sus menores gestosgestos calculados hasta el detalle más ínfimo - adquieren un relieve

\footnotetext{
${ }^{4}$ See, respectively, Brecht on Theatre (57-62, 91-99, 136-47) and The Theater and Its Double (53-73, 84-100).
} 
increíble. No se pierde un matiz, una sílaba del texto . . No hay manera de pensar en otra cosa . . Todo ocurre en una indescriptible atmósfera de violencia poética" (Crónicas 372; my emphasis).

These lines underscore Carpentier's fascination with the proscenial boundary between audience and spectator, a concern that he shared with major theatre innovators of his time-Piscator, Brecht, Artaud, Pirandello-who, for diverse ends, sought to cross these boundaries both literally and metaphorically. More Brechtian than Artaudian, Carpentier the spectator reflectively distanced himself from the scene. But his observations on Meyerhold's "poetic violence" in controlling spectator focus reveal that he was equally drawn to the possibility of crossing the other way-like the Pasos perdidos protagonist-from audience to stage. This allure of a possible "closure of representation" (Derrida's characterization of Artaudian theory) reveals Carpentier's attraction to the "participation mystique," a phenomenon that has permeated twentieth-century dramatic experiments. ${ }^{5}$ Thus he repeatedly noted the ability of theatre not only to concentrate spectator perception but also to stun and absorb the audience, as in the impact of a Meyerhold production's unexpected ending: "el espectador se siente completamente anonado por la emoción y la admiración . . . Estamos bajo el efecto de una suerte de estupor invencible" (374; my emphasis). These observations reveal Carpentier's discernment of theatre's potential for the perverse. Thus, although he was not an ardent Pirandello fan, he confessed to being involuntarily captivated by the violent technical virtuosity of his work, much like an opponent of boxing can be perverted by the power of a real-life match: "La violencia increíble del primer acto, su ritmo apretado, la atmósfera electrizada en que se mueven sus personajes, transforma en contendientes a los actores y espectadores" (398).

We can see here that Carpentier perceived the implicit paradox of performance: the estranging effect upon audiences in the unabashed theatricality of spectacles like the Beggars' Opera and their simultaneous capacity for luring the audience in. The Teatro del Piccoli's stylized marionettes epitomized this tension for Carpentier:

Esa estilización intensa . . hace que, durante los primeros momentos de una representación, experimentemos cierta extrañeza ante ellos; pero luego,

\footnotetext{
"See the chapter on "Repression, Pain, and the Participation Mystique" in Blau's The Audience.
} 
el automatismo de sus movimientos, la naturalidad de sus expresiones que solo varían según el ángulo en que los enfoca la luz, nos convencen del todo. Los miramos como si fueran actores hechos del mismo limo que nosotros. (Crónicas 328)

With its focus on spectator identification, this passage also displays Carpentier's interest in a performance's construction of character subjectivity through visual effect and spectator perception, the onstage embodiment of a "self-apprehended identity." His observations on Pirandello's inquiry into personality underscore this concern: "Lo maravilloso de su talento," he wrote, "está en mostrarnos cómo un mismo individuo, bajo la acción de los núcleos humanos que atraviesa, puede poseer un sinnúmero de personalidades" (404). Implicit in these observations is the idea that manipulating lighting, stage space, and proscenial boundary contributes not only to character portrayal but also to the spectator's own identity embodied in a concrete position from which to experience the stage's fictional world. Through his own theatrical experiments, Carpentier directed these concepts more specifically toward the encounters of cultural difference that so often concerned him.

\section{Carpentier's Theatrical Experiments}

Like many of his characters, Carpentier was a highly knowledgeable spectator and devotee of music, dance, drama, and film. He was also a dramatic practitioner and promoter. ${ }^{7}$ His performance pieces of this period - the Afro-Cuban ballets, El milagro de Anaquillé (1927) and La rebambaramba (1928), and the ópera bufa, Manita en el suelo (1931) - parallel his critical writings. But whereas the latter examine the theoretical problems of theatrical space and spectator position, the former pursue these ideas to enact the encounter between conflicting world views implicit in cultural difference.

While twentieth-century innovators like Brecht and Artaud radicalized conceptions of performance space and audience-stage relationships, more recent theory directs the issue of theatrical space

"I borrow this term from Steven Cohan and Linda M. Shires who use it as a preliminary definition of subjectivity (104).

${ }^{7}$ For a specific account of Carpentier's promotion of and participation in performance activities during his 1928-1939 Parisian years, see chapter one of Klaus MüllerBergh's biographical-critical study. 
toward the problem of subjectivity and identity. All performance, as Richard Schechner illustrates with reference to the work of Victor Turner, implies the creation of space that is physically and temporally separate from ordinary life $(10-16)$. Drawing on this idea of separation and mining the common terrain between theatre and anthropology, contemporary performance theory offers a definition broad enough to encompass the ritual of a traditional society, the full-dress enactment of a Shakespearean or Spanish Golden Age drama, and a late twentieth-century work of performance art. In any of these events, demarcations between the site of enactment and "real-world" space may be concretely visual or only imagined, but, through the process of performance, the spatial reconfiguration of that imagining is customarily shared by actors and spectators. These conventions, moreover, are culturally shared and acquired. Thus on the relationship of character construction to theatrical space, Charles Lyons argues that playwrights or directors can ascribe meaning to the mise en scène through the "perception and mediation of images" grounded in the agency of characters who "voice their perceptions of the environment in which they exist" ("Character" 31) and embody a particular way of "thinking of themselves in the world" ("Character" 34) that is, a specific identity and world view.

But in the kind of modern dramatic events that Carpentier witnessed and sought to create, character and spectator relationships to theatrical space are constantly reconfigured. Austin Quigley argues that, through such overlapping of spatial boundaries, much modern drama foregrounds the idea of "pluralistic worlds with pluralistic values" (9). Such shifts, I would argue, provide fertile ground for posing radically diverse identities through performance. Quigley argues further that a social pluralism "based on geographical or temporal variations" leads logically to the idea of "psychological pluralism in a single space at a single time," or, in other words, to a mobile subject position. He maintains that dramatized images of overlapping worlds lead audiences to focus on the horizons rather than the centers of discrete domains (13), and, I would extend his idea to add, the shifting horizons of identity constructed by reconfigurations of theatrical space. But if, as Lyons posits, audience conception of theatrical space is mediated through character perception and voicing, I would argue that it follows that shifting onstage relationships to space will also lead spectators into variable modes of "thinking of themselves in the 
world": into culturally inflected variations of self-apprehended identities.

Carpentier's three pieces of this period engage in a radical play with theatrical space and spectator position. All three portray onstage spectators of metaperformative events, all blur the lines between spectator space and performance space, all posit a connection between performance style and cultural identity, and all implicitly suggest that spectatorship itself constructs cultural identity embodied in a singular way of viewing the world. The fact that none of these works employs conventional dialogue (a quality shared with much of Carpentier's prose fiction) underscores the emphasis on watching: the two ballets have almost no spoken language, and in the ópera bufa, stylized words in song reinforce visual expressiveness. But while there is no speaking in Carpentier's highly imagistic works, characters articulate "voiced perceptions" of the world (Lyons' term) through body language or mime.

El milagro de Anaquille, a one-act "misterio coreográfico afrocubano," provides the simplest exposition of these concepts. In a stylized Cuban countryside scenario, cane cutters playing music at day's end are interrupted by two competing performances that vie for their attention: on one side of the stage, the filming of a Hollywood movie peppered with stereotypes of Hispanic life (a Spanish dancer, a bullfighter) and on the other, a ñanigo initiation ceremony. While a Business Man choreographs the former scene, an Iyamba leader of Afro-Cuban religious cults directs the latter. In demeanor and dress (including hyperbolically stylized masks), the directors embody modernist and primitivist stereotypes. The two events clash and intersect when the Business Man turns his cameras on the initiation ritual, a move the Iyamba thwarts with the greater power of two deities at his disposal. The piece's two discrete performance sites manifest two distinct worldviews, as well as the conflictive invasion of one space by actors from the other. The work's culturally inflected spectator relationships to performance space also give voice - through the play of vision - to distinct perceptions of the world. The Hollywood film-

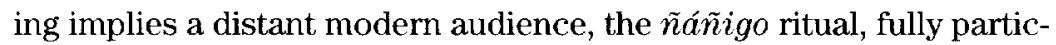
ipating initiates. The cane workers watching these competing representational modes occupy a position on the horizons of these worlds that shifts when the Business Man's invasion of the Iyamba's space redraws the boundaries between the two events. The work does portray the initiation ritual as the more powerful performative mode in 
its capacity to stun and absorb an audience, a position that echoes Carpentier's writing on Meyerhold and his attraction to the "participation mystique." But the cane workers' unstable viewing position duplicates the perceptual shifts and critical distance ascribed to the ballet's implied audience. ${ }^{8}$

La rebambaramba presents a more supple interplay of character and spectator positions and, by extension, of the ways in which these entities "think of themselves in the world." Set in slave-era Havana, the work depicts a carnivalesque celebration of Three Kings' Day. Here a Spanish soldier vainly pursues a popular Cuban "mulata." Following an opening street scene in which the soldier first courts the woman, the audience witnesses the interaction between onstage spectators and two comparsas, or groups of Afro-Cuban carnival players. Stage directions explain that performers and spectators onstage should maintain constant motion, a strategy that undermines audience efforts to distinguish between them. The piece ascribes to each group a concrete cultural identity, as each is invaded by a nonparticipant in its conventions. Foreign sailors intermingle with the roving audience of "lechuguinos, soldados, negros curros," and the foreign soldier, disguised as a masked diablito from ñánigo ritual intrudes on one of the comparsas. But dancers unmask him, crossing the boundary into a spectacle whose conventions he ignores, an outcome that highlights the cultural parameters of performing and watching.

Of the three compositions, Manita en el suelo presents the most complex construction of theatrical space and generates a more nuanced reflection on spectator positions and the cultural orientations they embody. Its deceptively simple dramatic action summons characters from Cuban folklore to tell, through declamatory song, how Manita deflated the moon. In this puppet play and ópera bufa, only the narrator Papá Montero is portrayed by a human actor, who mimes his words, and all lyrics (human and puppet) are performed by offstage singers. A complex interplay of space and spectator position undercuts the straightforward narration. The opera's most interesting feature is its concentration of spectator attention through the reduc-

\footnotetext{
${ }^{8}$ For a detailed analysis of this piece and the cultural positions it puts into play, see "Cultural Collisions Through Performance: El milagro de Anaquille" in my Latin American Vanguards (61-68). See also Frank Janney's commentary on these performance pieces in Chapter 1 of his study of Carpentier.
} 
tion of theatrical space that Carpentier had observed in Meyerhold's work and Italian marionette theatre. Manita en el suelo generates a mise en abîme of performance sites that not only channels audience focus into an ever-diminishing space but also constructs interlocking cultural positions through characters and spectators who embody distinct modes of "thinking of themselves" in the world.

The main-stage opening scene evokes a Cuban town on a fiesta day. From this space, the narrating Papá Montero directs audience attention to a little theatre center-stage, a thatched bohio without an audience-oriented fourth wall. In this "teatro de carpa" ambience, puppets enact the story he tells. The puppet characters in turn direct their attention to an even smaller framed space, a site for ñánigo ritual emanating supernatural light. Here the sacred figure "el Gallo Motoriongo" enthralls puppet onlookers with his song. Through these layers of spectatorship, the work constructs multiple culturally-inflected positions in relationship to enacted events. The stylized Cuban small-town setting from which Papá Montero narrates implies an audience from somewhere else. The bohio-style little theatre posits, in turn, an audience encompassing not only the narrator and the opera bufa spectators, but also the Cuban town inhabitants whom Papá Montero entertains and instructs with this folkloric fable of origins. Three distinct audiences watch the innermost, ñánigo event: Papá Montero and his audience, the small-town puppet play spectators, and the puppet characters in whose world the sacred rooster appears.

The discrete positions of these audiences highlight the fact that each embodies a different degree of identification with each level of performance. Each audience, moreover, watches the on-stage spectators within the next level. If we consider that this piece was composed during Carpentier's Parisian years, we can surmise that its primary implicit audience might well feel a cultural distance (corresponding to its physical position) from the events depicted in the tiny ñanigo site, while the puppet world inhabitants behold a religious scenario whose world view they share. But the nested performance sites reduce audience focus so sharply that even the primary opera bufa spectator might be drawn more closely into the nánigo scene. To further complicate character and spectator identities, performance spaces-and, by implication, spectator and character worlds - eventually intermingle. Manita, the puppet-show protagonist, bursts onto the main stage where Papá Montero narrates and, with his back to the main audience, comments on the puppet 
show action. Poised like the protagonist of $L P P$ on the boundaries between participation and reflection, Manita thus becomes a performing spectator, an alternately distanced and engaged watcher of a world within which he himself performs.

\section{Performance in Carpentier's Narrative World}

Carpentier's only conventional, full-length play, La aprendiz de bruja (1956), is, as theatre, his least successful work. Composed by invitation, the play dramatizes the La Malinche story in Cortés' defeat of Moctezuma's world. In keeping with Carpentier's enduring interest in cross-cultural encounters, the play juxtaposes the incompatible world views brought into conflict during these events and, through the didactic process of Doña Marina's gradual acculturation, highlights the conflictive dynamics of cross-cultural mis/readings. ${ }^{9}$ But as theatre the work is unwieldy, primarily due, I would suggest, to its cumbersome dialogue and the absence of precisely the kind of lively visual dynamics that characterize the early short works I have just described. The play's ponderous dialogue, in fact, projects the ambiance for a novel, but not, of course, a novel by Carpentier.

In narrative, dialogue was never Carpentier's strong suit, but not because his novels are monologic. Quite to the contrary, the pervasive "double-voicing" in his fictional world is an interplay not of quoted conversation but of perceptions, a profoundly theatrical strategy that constitutes his mode not only for telling a story but also for constructing culturally inflected subject positions, distinct ways of imagining oneself in the world. Drawing on Bakhtin's early philosophical writings, Michael Holquist has shown the strong links between his sociolinguistic conception of narrative-embodied in dialogism and heteroglossia-and his conception of the self. ${ }^{10}$ Subjectivity for Bakhtin is a dialogic relation, and in dialogism, the "very capacity to have consciousness" is based on "otherness." Holquist concludes that in Bakhtinian scenarios, the roles played by the self and other "always enact a drama containing more than one actor" (18; emphasis in original). What Bakhtin's writings on the self add to his linguistic conception of dialogism is the fundamental role

\footnotetext{
"See articles by María M. Carrión and Carmen Vásquez for analyses of this play.

19 "Discourse in the Novel" presents Bakhtin's most detailed exposition on dial ogism and heteroglossia.
} 
of perception. Thus dialogism becomes not only a linguistic exchange, but also an interactive drama between perceiver and perceived. This theatrical process is also a simple form of narrativity, that is, "the ability to put myself into scenarios of the kind I see others enacting" (37). For Bakhtin, in Holquist's reading, "subjectivity is the tale of how I get myself from the other . . . I see my self as I conceive others might see it" (28).

In Carpentier's novels, individual or group identity is often forged through such a dramatic dialogue of perception, an inquiry into spectatorship that refines his theatrical criticism and works. While a detailed examination of Carpentier's entire novelistic corpus lies beyond the scope of this essay, some key narrative examples illuminate how this dynamic of spectatorship articulates the search for a place in the world undertaken by almost all of his protagonists. Afro-Cubanism dominates early works like "Historia de lunas" (1933) and Écue-Yamba-O (1933), and, on the surface, these narratives' quest for the autochthonous idealizes Afro-Cuban ritual as a participatory performance that envelops actors and audience in its sacred sphere. But, through a shifting narrative focalization achieved primarily through free indirect discourse, a theatricalized dialogue of vision positions the reader-as-spectator variably toward events that unfold. Thus the narration in "Historia de lunas" slides from the ethnographic perspective of an outsider alien to the performative ritual - "Entonces Tata Cunengue interrogó al Santo que había bajado a su cuerpo, según las fórmulas que usaban los brujos para entenderse con los Santos"- to the insider's view of the ritual's purpose: "De una vez se acabaría con el escurridizo, la anguila, la semilla y el árbol. Y por fin se haría la paz" (231). Already in EYO, the autochthonous protagonist Menegildo Cué experiences a distance from his culture's performances analogous to that of the ethnographer, and sometimes these shifts are posed theatrically. The protagonist's first departure on all fours from the bed of sacks that has marked his horizons leads to his first prodigious discovery: a family altar. Overcome by the "participation mystique," to recall Blau's term, Menegildo experiences this site as a theatrical scenario that, as its spectator, he yearns to enter: "Mágico teatro, alumbrado levemente por unas candilejas diminutas colocadas dentro de tacitas blancas . . Menegildo alzó los brazos, asiéndose del borde de un mantel" (28). Later, Menegildo experiences the initiation into his culture's sacred ñánigo ritual as a proscenial shift from audience-like distance to performative immersion: "tras- 
puso la frontera del círculo mágico" (172). On the other hand, his estrangement from modern life in Havana is also cast in theatrical terms, when he perceives himself as a mere spectator to the street world's constant motion, and works in a carnival side-show as St. John the Baptist, a role he performs with Brechtian self-awareness.

These shifts between spectatorship and participation undermine Carpentier's own early ethnographic dichotomy between an imagined participatory autochthony and an alienated modern world, and theatricality in El reino de este mundo (1949) reinforces the subversion. Here the autochthonous Ti Noel, a protagonist characterized at the outset by his African origins, embodies shifting positions in relation to the narrated world, analogous to those constructed for the reader. ${ }^{11} \mathrm{~A}$ frequently cited scene from this novel, the execution by burning of the slave-rebellion leader Mackandal, portrays European (slave-holding) and autochthonous (Afro-Haitian) cultures in opposition precisely through the kinds of spectator-performance relationships they construct. The narrator builds this scene as an almost festive performative event with two interlocking audiences, the recaptured slaves who identify with Mackandal and the slave-holding families who watch them and the stake-burning simultaneously:

Como de palco a palco de un vasto teatro conversaban a gritos las damas de abanicos y mitones, con las voces deliciosamente alteradas por la emoción. Aquellos cuyas ventanas daban sobre la plaza, habían hecho preparar refrescos de limón y de horchata para sus invitados. Abajo, cada vez más apretados y sudorosos, los negros esperaban un espectáculo que había sido organizado para ellos; una función de gala para negros, a cuya pompa se habían sacrificado todos los créditos necesarios.

Much has been made of the fact that the narrator betrays his supposed Eurocentrism by intimating to the reader the truth of Mackandal's ultimate demise ${ }^{12}$ But through the dialogue of perceptionswhen Mackandal's body flies off the stake the slaves see him ascend and the slave-holders see him land in the flames - the narration once again destabilizes the reader's relationship to events and portrays a mutable position vis-a-vis performance as the key to a not-so-stable cultural identity. In this novel, moreover, Western theatricality becomes a site of sham and artifice, a reiterated motif in Carpentier's

\footnotetext{
"Amaryll Chanady carefully examines the shifts in narrative focalization weaving through El reino de este mundo.

${ }^{12}$ See Chanady, for example.
} 
later novels. This image is projected here through the extravagant histrionics of Mademoiselle Floridor, which are (mis)read literally by her Antillean audience, and through the theatrical power displays generated by the tyrannical monarch, Henri Christophe. Interestingly, however, performance also constitutes the locus of Ti Noel's development from a primarily passive observer of the events that surround him into a self-conscious agent in a fictional world whose dichotomy between decadent slave-holding Europeans and autochthonous characters endowed with self-present faith in the marvelous has already begun to collapse. After participating in the sacking of the Sans-Souci palace, he returns to the plantation of his youth and uses the booty to construct a scene around himself in which, as in a dramatic rehearsal, he puts on and takes off multiple identities, including that of Henri Christophe. ${ }^{13}$ Embodying a culturally mobile subjectivity, Ti Noel is the spectator of a drama that he simultaneously directs and enacts. But, like the narrator of $L P P$, he becomes fully aware of his interstitial position when, using the transformational powers learned from Mackandal, he immerses himself in another culture by joining a flock of geese. Like the anthropologist who goes native or the fake diablito in La rebambaramba, he learns painfully that, participation mystique notwithstanding, crossing the proscenial boundary to assume a role will not guarantee community: "Como Ti Noel sólo era un disfrazado, que en modo alguno se consideraba solidario de la Especie, se refugió, solo, debajo de su mesa" (139).

In its protagonist's fruitless quest for lost community through a return to sources, $L P P$ spells out much of what ERM had already posed. The equation of theatre with sham undergirds the novel's binary opposition of artifice and authenticity, most notably in its portrayal of women. Thus the protagonist flees his actress wife Ruth, whose condemnation to an interminable play-run embodies the tyranny of the mimetic, and then his lover Mouche, whose name evokes Sartrean scripts and who also incarnates imitation, in this case of European intellectual life. ${ }^{14}$ Although drawn to the less reflective Rosario (like the autochthonous audience in ERM, she absorbs fiction

\footnotetext{
${ }^{13}$ Lyons notes that the dramatic rehearsal exposes the "collision of readings" marking character subjectivity that is obscured by the unifying presence of an actor on stage characterizing an actual performance ("Beckett, Shakespeare, and the Making of Theory" 126).

${ }^{14}$ See Harvey for a close reading of theatricality and falsity in $L P P$ 's characterizations of women $(117-24)$.
} 
as if it were real life), at his journey's end the narrator finds only theatre and mimesis. Thus, what he believes to be the invention of music - the enactment of an indigenous funeral lament on primitive instruments - turns out to be not the desired moment of ontological unity but a double-voiced dialogue of song and countersong (244), an enactment of shifting responses to the same event. But $L P P$ 's focus on the theatrics of double voicing is more thematic than structural, for the sustained first-person narration limits the play of perspectives that marks most of Carpentier's narrative work. ${ }^{15}$ The notion of performance as a site of becoming - posed by Ti Noel's play-acting in ERM - appears most clearly again in El siglo de las luces (1962), a novel more varied in its focalization and saturated with scenes of performance: carnival celebrations, traveling theatres, and theatricalized power displays ${ }^{16}$ Perhaps more than any other work, ES ostends Carpentier's insights into the paradoxical status of performance as a site of liberation and perversity. In the novel's early scenes, the protagonists Esteban, Sofía, and Carlos mark their deliverance from parental rule through elaborate play-acting games that include transforming the space that surrounds them and assuming a variety of personas. Many have noted the importance of this scene for the protagonists' initiation into adulthood, but I would emphasize its significance as well for their trying on and taking off of varied identities, a rehearsal-style mobile subjectivity ${ }^{17}$ that characterizes Esteban, and to some degree, Sofía, throughout the novel. Sofía's reflection on the effects of these metamorphoses highlights the image of a subject in formation through performance: "sentíase ajena, sacada de sí misma, como situada en el umbral de una época de transformaciones" (48). The fact that the youths are simultaneously performers and spectators of these homemade dramas, moreover, anticipates the interstitial position Esteban in particular occupies in events that follow. As a character with a minor role in the French revolutionary milieu, Esteban imagines himself as a fugitive from the sidelines sud-

\footnotetext{
${ }^{15}$ Gustavo Pérez Firmat demonstrates, however, that this novel constructs an implicit double-voicing through the elusive language of its composition that suggests we are reading a translation of a work written by somebody in a language that is not his first (138-57). Germán Guilón, moreover, finds perspectivism in the duality of the protagonist.

${ }^{16}$ González Echevarria notes that $E S$ interweaves scenes from eighteenth-century French drama (Isla 180).

${ }^{17}$ See note 13 .
} 
denly immersed into an enormous spectacle: "tenía la impresiónluego de tanto vivir en lo retirado y recoleto-de haber caído en una enorme feria, cuyos personajes y adornos hubiesen sido ideados por un gran intendente de espectáculos" (95). But at other moments the perspective shifts and he assumes more of a spectator's position, contemplating, like Menegildo Cué before the family altar, a scene that lures him in: "Cada tienda le resultaba un teatro, con el escaparate-escenario" (96). More often than not, Esteban recognizes his own marginal, spectatorly position vis-a-vis historical events, but key moments shock him with the recognition of his own shifting, paradoxical identity as a participating witness: "Nada era tan semejante a una pesadilla como aquel escenario donde se contemplaba a sí mismo, durmiente despierto, juez y parte, protagonista y espectador" (188; my emphasis).

The tensions between self-reflection and participatory immersion in this work, embodied in Esteban's and Sofía's respective relationships to the novel's historical events, evoke the struggles within Carpentier himself - noted by numerous critics - about his identity as an intellectual who rarely engaged directly with the historical dramas through which he lived, such as the Spanish Civil War or the Cuban Revolution. ${ }^{18}$ Notwithstanding Esteban and Sofía's final immersion in the scene of the Spanish people's anti-Napoleonic rebellion, a conclusion that many read as Carpentier's desire for political commitment, ES exhibits a simultaneous ambivalence toward total absorption in the historical scenario. The novel, in fact, allegorically exposes the perversity of the twentieth century's participation mystique and utopian quest for an epiphanic communal spectacle, underscoring the dangers in the abolition of reflection implicit in a total erasure of boundaries between audience and enactment. Such is the quotidian, communal danse macabre activated by the guillotine's arrival in Guadalupe, a scene anticipated by the violence of spectator immersion that Carpentier had discemed years earlier in Meyerhold's scenic manipulations:

Aquí no se tenía nada semejante; nunca habíase visto un escenario abierto a todos, y por lo mismo descubrían las gentes, en aquel momento, la esencia

${ }^{18}$ See, for example, González Echevarría (The Pilgrim 276-88), Harvey (135-39), or Donald Shaw (108-10). Harvey argues that, through the theatre metaphor, Carpentier portrays characters like Esteban and Sofía in ES as "progressing from the role of spectator to that of actor in the drama of life" (135). 
de la Tragedia. El Fatum estaba ya presente con su filo en espera, inexorable y puntual, acechando a quienes, por mal inspirados, habían vuelto sus armas contra la Ciudad. Y el espíritu del Coro se hallaba activo en cada espectador, con las estrofas y antiestrofas que brincaban y rebrincaban por encima del tablado. (154)

It is equally telling, moreover, that the character for whom the novel reserves both its greatest fascination and its harshest judgement is Victor Hugues, who, devoid of the Brechtian gestus ${ }^{19}$ or the Bakhtinian double vision that often marks Esteban and even Sofia, repeatedly mistakes theatre for life, his performance for his persona: "En menos de diez años, creyendo maniobrar mi destino, fui llevado por los demás . . . a mostrarme en tantos escenarios que ya no sé en cuál me toca trabajar. He vestido tantos trajes que ya no sé cuál me corresponde" (342). While still struggling with the dilemma of commitment to the decisive moments of one's era, this novel veers away from the alluring "closure of representation" motivating the $L P P$ quest and opts instead for the cognitive value of performance's ironic proclivity for unmasking its own terms. By ultimately privileging Esteban's experience, and its counterpoint in Sofía's advance toward and retreat from Víctor's performative mode, the novel tacitly valorizes the performing spectator's mode of reflective action.

El recurso del método (1974) reinforces this interplay of self-contemplation and action through its dictator-protagonist, who is as adept at role-shifting as Víctor Hugues, but as prone to reflecting on his own performances as Esteban. Well known for his appetite for drama's hyperbole - the opera - the Primer Magistrado literally fashions his own parts in scenarios also of his own orchestration, an activity anticipated in the novel's opening scenes: in a fitting with his tailor, he witnesses his transforming persona and fancies himself at the center of a set piece for which the room's sumptuous objects provide the props. The novel's shifts in narrative voicing (from first to third person) and focalization (the Primer Magistrado also describes himself both from within and without) draw the reader-asspectator into its Bakhtinian dialogue of perceptions. Subsequent novels like La consagración de la primavera (1978) and El arpa y la sombra (1979) further elaborate various aspects of ES's thematic

\footnotetext{
${ }^{19}$ I am referring here to Brecht's advocacy of a self-conscious separation between actor and character, in which the former is to enunciate the words of the latter "like a quotation" (138).
} 
terrain; however, more than any other work, Concierto barroco (1974) synthesizes - and celebrates-Carpentier's life-long inquiry into performance. In this novella, moreover, the anxiety about political commitment seems to be momentarily muted by a reaffirmation of the power of creativity and reflection for any historical enterprise. Critics have given a primarily allegorical reading to the work's portrayal of an early eighteenth -century Venetian encounter, during carnival time, of a wealthy Mexican criollo, his black Cuban servant, and the European composers Vivaldi, Scarlatti, and Handel. The ensuing carnivalesque "concierto barroco" (a jam session, in Donald Shaw's words) is seen to embody the creative cultural hybridity Carpentier ascribes to the New World, and the artistic project of a new Western art in which the New World fruitfully contaminates the old (González Echevarria, The Pilgrim 267). ${ }^{20}$

But this work may also be read complementarily as the story of two performances and the spectators who witness them. In the jam session, performers and spectators from multiple origins - most in carnival costume - become one, not in a frenzied dance of death, but in a ribald celebration of music and dance. The staging of Vivaldi's opera Montezuma provides the work's second central event, a performance narrated through the eyes of two very talkative spectators, the Mexican criollo and the Cuban servant. Throughout the enactment, the Mexican - in a manner recalling Carpentier's Parisian theatre reviews-expresses a range of reactions to the events on stage: at times they are false representations of what he regards to be the history of his own homeland, and at others, he is totally drawn in by what he sees. The servant, on the other hand, articulates his sometimes quite different views of the actors on stage. As in ERM and Carpentier's early dramatic compositions, here we have two spectators who, based on their differences of culture (Mexico/Cuba) and class (master/servant), experience this event in dissimilar ways. Like characters in a play, they also voice different perceptions of the space they observe and vicariously inhabit.

This novella diverges from Carpentier's prior inquiries into performance in two ways. As the Mexican master and the Cuban servant watch a performance side by side, two distinct audiences are positioned not in dramatic opposition but through an actual present-tense

${ }^{20}$ In its focus on cultural syncretism, Shaw's reading of Concierto barroco is akin to that of González Echevarría. 
conversation, a no longer silent but expressly-voiced dialogue of dissimilar perceptions and identities. In a subsequent discussion about the purpose of theatre, moreover, the Mexican underscores its importance, in its very fraudulence, to a sense of cultural participation and self-definition: "Ante la América de artificio del mal poeta Giusti, dejé de sentirme espectador para volverme actor . . . . Me parecía que el cantante estuviese representando un papel que me fuera asignado, y que yo, por blando, por pendejo, hubiese sido incapaz de asumir . . . . A veces es necesario alejarse de las cosas, poner un mar de por medio, para ver las cosas de cerca" (198). This portrayal of the dramatic experience sidesteps Carpentier's long-standing dichotomy, recurrently undermined by the author himself, between Western theatrical sham and a utopian closure of representation. To the contrary, this novella embraces the theatrical for its conceptual richness and its potential for effective cross-cultural transaction. Here performance and spectatorship, moreover, appear as still-distinct but no longer incompatible or mutually exclusive activities, and active spectatorship becomes a reflection on the effectively performed life. Even as an emblem of artifice, theatre-and the performance that renders it palpable - become sites of multiple maneuvers: communication, inquiry, creativity, celebration, and a nuanced rethinking of one's place in the world.

\section{WORKS CITED}

Artaud, Antonin. The Theater and Its Double. Trans. Mary Caroline Richards. New York: Grove, 1958.

Bakhtin, M. M. "Discourse in the Novel." The Dialogic Imagination: Four Essays. Ed. Michael Holquist. Trans. Caryl Emerson and Holquist. Austin: U of Texas P, 1981. 259-422.

Blau, Herbert. The Audience. Baltimore: Johns Hopkins UP, 1990.

—_. Blooded Thought: Occasions of Theatre. New York: PAJ, 1982.

Bost, David. "The Operatic World of Concierto barroco." Cincinnati Romance Review 7 (1988): 113-24.

Brecht, Bertolt. Brecht on Theatre: The Development of an Aesthetic.

Ed. and trans. John Willett. New York: Hill and Wang, 1964.

Carpentier, Alejo. Obras completas. Mexico: Siglo Veintiuno, 1983.

__. La aprendiz de bruja. Obras completas 4. 25-143.

Concierto barroco. Obras completas 4. 145-214.

_.... Crónicas 1: Arte, literatura, politica. Obras completas 8. 
Ecue-Yamba-O. Barcelona: Bruguera, 1979.

"Historia de lunas." El milagro de Anaquillé. La rebambaramba. Manita en el suelo. Obras completas 1. 221-38; 263-77; 195-207; 239-61.

_-.. Los pasos perdidos. Ed. Roberto González Echevarría. Madrid: Cátedra, 1985.

—. El recurso del método. Obras completas 6 .

- El reino de este mundo. Barcelona: Seix Barral, 1983.

. El siglo de las luces. Barcelona: Seix Barral, 1964.

Carrión, María M. "La voz traductora en La aprendiz de bruja de Alejo Carpentier." Revista de Estudios Hispánicos 25.1 (1991): $49-67$.

Chanady, Amaryll. "La focalización en El reino de este mundo." Critica Semiológica de Textos Literarios Hispánicos. Vol. 2 of Actas del Congreso Internacional sobre Semiótica e Hispanismo. Ed. Miguel Ángel Garrido Gallardo. Madrid: Consejo Superior de Investigaciones Científicas, 1986. 485-92.

Cohan, Steven and Linda M. Shires. Telling Stories: A Theoretical Analysis of Prose Fiction. New York: Routledge, 1988.

Collard, Patrick. "La máscara, el traje y lo teatral en Los pasos perdidos de Alejo Carpentier." Actas del IX Congreso de la Asociación Internacional de Hispanistas, vol. 2. Frankfurt am Main: Verlag, 1989. 507-14.

Derrida, Jacques. "The Theater of Cruelty and the Closure of Representation." Writing and Difference. By Derrida. Trans. Alan Bass. Chicago: U of Chicago P, 1978. 232-50.

Freedman, Barbara. "Frame-Up: Feminism, Psychoanalysis, Theatre." Performing Feminisms: Feminist Critical Theory and Theatre. Ed. Sue-Ellen Case. Baltimore: Johns Hopkins UP, 1990. 5476.

González, Aníbal. "Ética y teatralidad: El Retablo de las Maravillas de Cervantes y El arpa y la sombra de Alejo Carpentier." La Torre 7.27-28 (1993): 485-502.

González Echevarría, Roberto. Alejo Carpentier: The Pilgrim at Home. Rev. ed. Austin: U of Texas P, 1990.

__. Isla a su vuelo fugitiva. Madrid: José Porrúa Turanzas, 1983.

Gullón, Germán. "El narrador y la narración en Los pasos perdidos." Cuadernos Hispanoamericanos 263.64 (1972): 501-09.

Harvey, Sally. Carpentier's Proustian Fiction: The Influence of Marcel Proust on Alejo Carpentier. London: Támesis, 1994. 
Holquist, Michael. Dialogism: Bakhtin and His World. New York: Routledge, 1990.

Hughes, Psiche. "The Visual and Performing Arts in the Work of Alejo Carpentier: El siglo de las luces." Revista/Review Interamericana 13.1-4 (1983): 126-37.

Janney, Frank. Alejo Carpentier and His Early Works. London: Támesis, 1981.

Lyons, Charles R. "Beckett, Shakespeare, and the Making of Theory." Around the Absurd: Essays on Modern and Postmodern Drama. Ed. Enoch Brater and Ruby Cohn. Ann Arbor: U of Michigan P, 1990. $97-127$.

- "Character and Theatrical Space." The Theatrical Space. Themes in Drama, vol. 9. Ed. James Redmond. Cambridge: Cambridge UP, 1987. 27-44.

Müller-Bergh, Klaus. Alejo Carpentier: Estudio biográfico-crítico. New York: Las Américas, 1972.

Pérez Firmat, Gustavo. The Cuban Condition: Translation and Identity in Modern Cuban Literature. Cambridge: Cambridge UP, 1989.

Quigley, Austin. The Modern Stage and Other Worlds. New York: Methuen, 1985.

Schechner, Richard. Performance Theory. Rev. ed. New York: Routledge, 1988.

Shaw, Donald. Alejo Carpentier. Boston: Twayne, 1985.

Unruh, Vicky. Latin American Vanguards: The Art of Contentious Encounters. Berkeley: U of California P, 1994.

Vásquez, Carmen. "La aprendiz de bruja: drama en tres actos de Alejo Carpentier." Revista de Estudios Hispánicos 13 (1986): 5370 . 